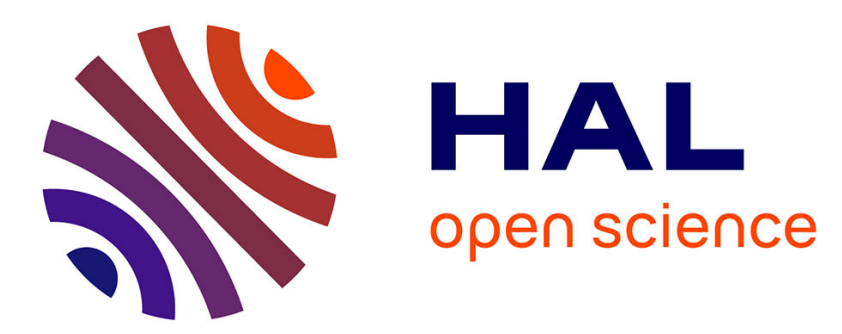

\title{
Electrical conductivity of partial molten carbonate peridotite
}

Takashi Yoshino, Elizabeth Mcisaac, Mickaël Laumonier, Tomoo Katsura

\section{To cite this version:}

Takashi Yoshino, Elizabeth Mcisaac, Mickäl Laumonier, Tomoo Katsura. Electrical conductivity of partial molten carbonate peridotite. Physics of the Earth and Planetary Interiors, 2012, 194-195, pp.1-9. 10.1016/j.pepi.2012.01.005 . insu-00662255

\section{HAL Id: insu-00662255 \\ https://hal-insu.archives-ouvertes.fr/insu-00662255}

Submitted on 17 Jan 2018

HAL is a multi-disciplinary open access archive for the deposit and dissemination of scientific research documents, whether they are published or not. The documents may come from teaching and research institutions in France or abroad, or from public or private research centers.
L'archive ouverte pluridisciplinaire HAL, est destinée au dépôt et à la diffusion de documents scientifiques de niveau recherche, publiés ou non, émanant des établissements d'enseignement et de recherche français ou étrangers, des laboratoires publics ou privés. 


\section{Accepted Manuscript}

Electrical conductivity of partial molten carbonate peridotite

Takashi Yoshino, Elizabeth McIsaac, Mickael Laumonier, Tomoo Katsura

PHYSICS

OF THE EARTII

AND PLANETARY

INTERIORS

PII:

S0031-9201(12)00013-1

DOI:

10.1016/j.pepi.2012.01.005

Reference:

PEPI 5496

To appear in:

Physics of the Earth and Planetary Interiors

Received Date:

24 April 2011

Revised Date:

9 January 2012

Accepted Date:

12 January 2012

Please cite this article as: Yoshino, T., McIsaac, E., Laumonier, M., Katsura, T., Electrical conductivity of partial molten carbonate peridotite, Physics of the Earth and Planetary Interiors (2012), doi: 10.1016/j.pepi.2012.01.005

This is a PDF file of an unedited manuscript that has been accepted for publication. As a service to our customers we are providing this early version of the manuscript. The manuscript will undergo copyediting, typesetting, and review of the resulting proof before it is published in its final form. Please note that during the production process errors may be discovered which could affect the content, and all legal disclaimers that apply to the journal pertain. 


\section{Electrical conductivity of partial molten carbonate peridotite}

2 Takashi Yoshino $^{1 *}$, Elizabeth McIsaac ${ }^{2}$, Mickael Laumonier ${ }^{3}$ and Tomoo Katsura ${ }^{1,4}$

3 'Institute for Study of the Earth's Interior, Okayama University, Misasa, Tottori 682-

4 0192, Japan

$5 \quad{ }^{2}$ Department of Earth Sciences, Dalhousie University, Edzell Castle Circle, Halifax NS, 6 B3H 4J1, Canada

$7 \quad{ }^{3}$ Université d'Orléans, Université François Rabelais - Tours, CNRS/INSU, Institut des

8 Sciences de la Terre d'Orléans - UMR 6113, Campus Géosciences 1A, rue de la

$9 \quad$ Férollerie 45071 Orléans cedex 2, hFrance

${ }^{4}$ Bayerisches Geoinstitut, Universität Bayreuth, 95447 Bayreuth, Germany

11 Abstract In order to investigate the effect of carbonate-content in partial melt on bulk conductivity under high pressure, electrical conductivity measurements were performed on carbonate melt-bearing peridotites using a Kawai-type multi-anvil apparatus. The starting materials were composed of spinel lherzolite (KLB1) with small amounts of dolomite ( 1 and 3 wt.\%). To obtain various melt fractions, annealing experiments were performed at different temperatures above $1400 \mathrm{~K}$ at $3 \mathrm{GPa}$. At low temperatures $(\leq$ $1500 \mathrm{~K}$ ), the conductivity was distinctly higher than that of carbonate-free peridotite and close to that of the carbonatite melt-bearing olivine aggregates. Although the

9 sample conductivity increased with increasing temperature, the rate at which the conductivity increases was small and the conductivity approached that of silicate meltbearing peridotite. $\mathrm{CO}_{2}$ concentration in the partial melt decreased with increasing annealing temperature. Thus, the small increase of the conductivity with annealing temperature is attributed to a decrease of the melt conductivity due to a decrease in 
carbonate content in the partial melt. As the carbonate concentration in the melt decreases, the estimated melt conductivity approaches that of the basaltic melt. Therefore, conductivity enhancement by the carbonate-bearing melt is very effective at temperature just above that of the carbonate peridotite solidus.

Keywords: Carbonatite; Electrical conductivity; Melt fraction; Peridotite; Upper mantle

\section{Introduction}

The high conductivity anomaly in the upper mantle is a general feature beneath the oceanic lithosphere as observed by electromagnetic surveys (e.g., Lizarralde et al., 1995; Evans et al., 2005; Baba et al., 2006). There are two major candidates for what causes the raising of the conductivity in that region: partial melt and hydration of nominally anhydrous minerals (e.g., Tyburczy and Waff, 1983; Karato, 1990). However, the electrical conductivity of hydrous olivine is not high enough to explain the conductivity anomaly at the top of the asthenosphere (Yoshino et al., 2006; 2009a; Poe et al., 2009). Recently Gaillard et al. (2008) proposed that a very small amount of carbonatite is an attractive agent for generating the conductivity anomaly based on the conductivity measurement of carbonate melts at atmospheric pressure. Later research showed the conductivity measurement of carbonate melt-bearing olivine aggregates at 3

GPa had an order of magnitude higher conductivity than the silicate melt-bearing olivine aggregates for the same melt fraction (Yoshino et al., 2010). In addition, carbon in peridotite can significantly reduce the solidus temperature (e.g., Falloon and Green, 1989; Dasgupta and Hirschmann, 2006). Thus the presence or absence of carbonatite melt will affect the estimation of mantle temperature from the conductivity structure of the upper mantle obtained from geophysical surveys. 
Yoshino et al. (2010) reported on the effect of carbonatitic partial melt with

higher carbon concentration on the bulk conductivity. However, partial melts of carbonate-bearing mantle peridotites may have variable carbonate concentrations under a wide range of mantle conditions. Thus, to assess conductivity anomalies in the upper mantle, we need to know the effect of the carbonate component in partial melt on the bulk conductivity of the partially molten peridotite under high pressure. In this study, we determined the electrical conductivities of carbonate-bearing peridotite with variable melt fractions. A variation of melt fractions was obtained by annealing under different temperature conditions. Since we used starting materials with a fixed carbonate concentration, the variation in the degree of partial melting can provide the variation in carbonate concentration in the partial melt. In addition, we measured conductivity of dolomite melt in order to constrain the absolute conductivity and activation enthalpy of carbonate melt at high pressure. The electrical conductivity of carbonate-bearing melt was estimated as a function of $\mathrm{CO}_{2}$ concentration in the melt. We obtained $\mathrm{CO}_{2}$ concentration dependence of electrical conductivity by comparing the data obtained from our previous results, in which the conductivity was obtained for the partial molten carbonate peridotite with fixed $\mathrm{CO}_{2}$ concentration in melt. Such an argument provides the constraints on the presence of carbonate partial melt and on the thermal structure of the upper mantle.

\section{Experimental Methods}

Starting materials were powder mixtures of natural spinel lherzolite (KLB1)

69 with 1 and 3 wt. \% natural dolomite from Austria, which have approximately 0.5 and 1.5 wt.\% bulk $\mathrm{CO}_{2}$, respectively. For one experiment, a powder of the KLB1 without dolomite was used as a starting material to investigate the effect of carbonate on electrical conductivity. Dolomite powder was also used as a starting material to measure conductivity of dolomite melt. The particle size of the powder was less than a few 
micrometers. The powdered sample was encapsulated in a cylindrical $\mathrm{MgO}$ sleeve and was sandwiched by two graphite electrodes in contact with two sets of $W_{97} R_{3}-W_{75} R_{25}$ thermocouples. Two sets of thermocouples were also used for the four-pole resistance method of electrical conductivity measurement. The design of the cell assembly is the same as that given in Yoshino et al. (2010).

Conductivity measurement with impedance spectroscopy was carried out using a Solartron 1260 impedance Gain-Phase Analyzer combined with a Solartron 1296 interface. Complex impedances were obtained at frequencies ranging from $0.1 \mathrm{~Hz}$ to 1 MHz and applied voltages of 1 or $1.41 \mathrm{~V}$. We applied the pseudo 4-pole electrode system to the conductivity measurement, because the resistance of the electrode and long metallic wires (thermocouple) can be comparable to that of the highly conductive melt (Pommier et al., 2010).

Conductivity measurements were conducted through several heating-cooling cycles at $3 \mathrm{GPa}$ in a Kawai-type multianvil press. The temperature was increased and decreased in steps of $25-50 \mathrm{~K}$ to the desired temperature. Impedance spectra were obtained at each temperature step. Firstly the sample was heated and held at $1000 \mathrm{~K}$ to dehydrate the sample and the surrounding materials. Then the sample was heated to the desired temperature, which is above the solidus of carbonate-bearing peridotite $(\sim 1350$ $\mathrm{K}$ at 3 GPa: Dasgupta and Hirschmann, 2006). To achieve textural equilibrium of the solid-liquid composites, the samples were annealed at the desired temperature, by continuous monitoring of electrical conductivity, until the sample conductivity became

5 constant. After annealing, the sample was cooled to less than $1000 \mathrm{~K}$. Subsequent heating cycles using step-wise temperature increments were also conducted to confirm reversibility. In order to retain the partial molten texture, the sample was quenched from the highest temperature to ambient temperature. 
Retrieved samples were mounted in epoxy and ground parallel to the axis of the cylindrical heater. The chemical compositions of the carbonate and silicate phases in the recovered sample were obtained using electron microprobe analyzer (EPMA). The carbonate $\left(\mathrm{CO}_{2}\right)$ concentration in the melt was predicted from the total weight deficit of the EPMA data (Table 2). However, the near-solidus partial melt composition could not be determined because of its small size $(<1 \mu \mathrm{m})$. The microstructure on the polished section of the run products was observed by secondary electron and back-scattered electron images (BEI) using a field-emission scanning electron microscope (FE-SEM). The melt fraction of the samples was determined from the image analysis after the experiments (for detail, see Yoshino et al. (2005)).

\section{Results}

\subsection{Texture and chemical composition}

The melt fraction of carbonate-bearing peridotite increased with increasing the annealing temperature (Table 1), whereas the carbonate-free peridotite annealed at 1700 K showed the absence of a melt phase. Microstructures on the polished section are shown in Fig. 1. Carbonate-bearing melt was located at the triple junction of the olivine and pyroxene crystals (Fig. 1a-c). As the melt fraction increased, the melt completely surrounded the olivine crystals on the polished section (Fig. 1d). The apparent dihedral angle was around $20^{\circ}$, which implies a three-dimensional interconnection of the melt network. Infiltration of the melt into the $\mathrm{MgO}$ capsule was not observed for all run products. Partial melt was homogeneously distributed in the center of the sample, whereas the melt-less olivine layer was also developed adjacent to the $\mathrm{MgO}$ container with a thickness of less than $100 \mu \mathrm{m}$. Forsterite content ( $\left.\mathrm{Fo}_{96}\right)$ in the olivine adjacent to the $\mathrm{MgO}$ container was relatively higher because of iron loss from the sample to the $\mathrm{MgO}$ capsule. The samples showed relatively homogeneous distribution of the melt, and therefore we believe the measured conductivity values should represent the whole part 
of the partially molten zone. As mentioned above, the outer part of the sample had less iron contents. The sample conductivity of the uncontaminated part of the sample should be slightly higher than the obtained value (less than $10 \%$ ).

For the 3 wt.\% dolomite-bearing peridotite system, the dolomite completely decomposed below $1600 \mathrm{~K}$. Orthopyroxene disappeared because of a decarbonation reaction such as $\mathrm{MgSiO}_{3}$ (in orthopyroxene) $+\mathrm{MgCO}_{3}$ (in dolomite) $=\mathrm{Mg}_{2} \mathrm{SiO}_{4}$ (in olivine) $+\mathrm{CO}_{2}$. Clinopyroxene was present up to $1700 \mathrm{~K}$, although by volume the proportion of clinopyroxene decreased with increasing temperature. The carbonate concentration $\left(\mathrm{CO}_{2}\right)$ in the partial melt of the samples decreased from 45 to $13 \mathrm{wt} . \%$ with increasing melt fraction from 0.02 to 0.2 (Tables 1 and 2). In the case of the KLB1 +1 wt. $\%$ dolomite system, the $\mathrm{CO}_{2}$ concentration in melt decreased to $5 \mathrm{wt} . \%$ when the melt fraction was 0.20 . We were not able to measure the melt composition accurately for samples containing the lowest melt fraction $(\leq 1 \mathrm{vol} . \%)$ using the electron microprobe. However, the carbonate component of the sample is usually expected to be 40 wt.\% just above the solidus (Dasgupta et al., 2007). Thus the $\mathrm{CO}_{2}$ concentration in the partial melt largely decreased with increasing annealing temperature and melt fraction. The $\mathrm{CO}_{2}$ concentrations in the melt estimated by EPMA were slightly higher than those expected from the bulk composition. For example, when we assume that all carbons partition into the melt phase, and the densities of the carbonate and basaltic melt range from 2 to $2.7 \mathrm{~g} / \mathrm{cm}^{3}$ (e.g., Dobson et al., 1996; Rigden et al., 1986), the KLB1 + dolomite $3 \mathrm{wt} . \%$ system with 20 vol. $\%$ melting requires around $10 \mathrm{wt} . \% \mathrm{CO}_{2}$ concentration in the partial melt. The $\mathrm{CO}_{2}$ concentrations in the melt were increased by partial solidification of the melt due to reaction with the $\mathrm{MgO}$ capsule.

\subsection{Electrical conductivity}

The impedance spectra generally show one arc at higher frequencies and an additional part appearing at lower frequencies (Fig. 2). If the melt phase is 
interconnected in a solid matrix, it forms an electrical pathway in parallel to the solid matrix (Roberts and Tyburczy, 2000). Thus the high-frequency arc reflects the sample properties, and the low frequency tail is accordingly interpreted as an effect of the electrodes. Therefore, only the first arc was used to determine the conductivity of the sample. As shown in Fig. 2b, the impedance spectra were sometimes observed to contain a predominantly inductive reactance (inductive loop) possibly due to the mass transport and electrochemical reaction at the electrode interface (Hampton et al., 1980; van Hassel et al., 1991). However, errors in conductivity values created by the induction component are small (less than $10 \%$ ), and therefore we reserve a detailed argument on the inductive component.

Fig. 3 shows the conductivity of dolomite up to $1800 \mathrm{~K}$ in Arrhenian plot. In the first heating, the conductivity largely increased by nearly two orders of magnitude at $1300 \mathrm{~K}$ and then increased by one order of magnitude at $1500 \mathrm{~K}$. Above $1600 \mathrm{~K}$, an increase of conductivity with temperature became small. After annealing at $1800 \mathrm{~K}$, the conductivity slightly decreased with decreasing temperature. The high conductivity values $(10 \mathrm{~S} / \mathrm{m})$ were retained even after cooling below the melting temperature. Above $1500 \mathrm{~K}$ the good linear relation in Arrhenius plot was observed. Conductivitytemperature relationships were determined from Arrhenian fits to the data for each sample

$$
\sigma=\sigma_{0} \exp \left(-\frac{H}{k T}\right)
$$

17 where $k$ is the Boltzmann constant and $T$ is temperature in K. Activation enthalpies $(H)$ and pre-exponential terms $\left(\sigma_{0}\right)$ resulting from fitting Eq. (1) to the data are listed in Table 1. The calculated activation enthalpy for electrical conduction in dolomite melt is $38 \mathrm{~kJ} / \mathrm{mol}$, which is slightly higher than the values $(30-35 \mathrm{~kJ} / \mathrm{mol})$ reported from Gaillard et al. (2008). The pre-exponential factor $\left(\sigma_{0}\right)$ for electrical conduction in 
dolomite melt is $1343 \mathrm{~S} / \mathrm{m}$, which is lower than the values $(3440 \mathrm{~S} / \mathrm{m})$ reported from Gaillard et al. (2008). Therefore, the absolute conductivity value of the dolomite melt was slightly lower than those of alkali carbonate melt $\left[\mathrm{KCa}_{0.5}\right]_{2}\left(\mathrm{CO}_{3}\right)_{2}$, $\left(\mathrm{NaKCa}_{0.5}\right)_{2}\left(\mathrm{CO}_{3}\right)_{3},(\mathrm{NaKCa})\left(\mathrm{CO}_{3}\right)_{2},(\mathrm{NaK})_{2}\left(\mathrm{CO}_{3}\right)_{2}$, and $\left.(\mathrm{LiNaK})_{2}\left(\mathrm{CO}_{3}\right)_{3}\right]$ reported by Gaillard et al. (2008).

An example of the conductivity measurements for the partial molten system is shown in Fig. 4a. The conductivity values were initially high and rapidly decreased during annealing at $1000 \mathrm{~K}$ because of the dehydration of surrounding materials. In the second heating, the conductivity largely increased by nearly two orders of magnitude up to $1100 \mathrm{~K}$. This temperature is consistent with the temperature at which the conductivity of Ca-rich carbonate abruptly increases during heating (e.g. Gaillard et al., 2008). Above $1200 \mathrm{~K}$, the conductivity slightly increased with increasing temperature up to $1500 \mathrm{~K}$. At the beginning of annealing at $1500 \mathrm{~K}$, the sample conductivity rapidly decreased and then became constant within 2 hours, similar to our previous studies (Yoshino et al., 2010). At the beginning of partial melting, the powder with large porosity was instantaneously filled with melt. Therefore, the conductivity was initially high. As the system established textural equilibrium during annealing, some pores were closed to minimize the total interfacial energy in the system. This process led to the reduction of the bulk conductivity of the sample. The impedance spectra showed part of a semicircular shape at higher frequencies, suggesting that the conductive phase forms an electrical pathway parallel to the solid matrix, and an additional part derived from electrode reaction at the interface between the sample and electrode at lower frequencies (Fig. 2). In the cooling path, the electrical conductivity decreased with decreasing temperature. The temperature-conductivity path in the Arrhenius plot showed linear trends with some different slopes, suggesting the conduction mechanism changes in a certain temperature range. In the subsequent heating path, the reproducibility was confirmed. 
In the third heating, the conductivity values at the highest temperature were identical to those just after the annealing for a few hours at the same temperature in the second heating (Fig. 4a). The samples were quenched from the highest temperature to obtain the partial molten texture of the final state. The conductivity values shown in Table 1 were obtained just before quenching. Therefore, the sample texture and the conductivity values represent the same condition as the second heating. Fig. 5 shows a plot of the conductivity values at the maximum temperature and melt fraction against the highest temperature experienced for each sample. The electrical conductivity of the partial molten sample generally increased with increasing temperature. The melt fraction increased from 0.01 to 0.20 in the investigated temperature range from 1400 to $1700 \mathrm{~K}$.

Fig. $4 \mathrm{~b}$ shows the logarithmic plot of conductivity versus reciprocal temperature for the KLB1 + dolomite $3 \mathrm{wt} . \%$ system in the second cooling path. The electrical conductivity of the carbonate-bearing peridotite is distinctly higher than that of carbonate- and melt-free peridotite, which is similar to that of olivine (Constable 2006; Yoshino et al., 2006; 2009). The samples annealed at higher temperatures showed lower conductivity values at the same temperature, and larger temperature dependence compared with the sample annealed at lower temperatures. Although samples have the same bulk composition, the fact that the cooling paths in the Arrhenius plot are largely different suggests that the chemical composition of the melt phase did not change significantly during cooling. In other words, chemical equilibrium in the system was established at the highest temperature, but not held during cooling. The activation enthalpy for electrical conductivity of carbonate melt is smaller than those of silicate melts (e.g., Presnall et al., 1972; Gaillard et al., 2008). A small temperature dependence on the conductivity of samples annealed at lower temperature was quite similar to that of dolomite end member, suggesting that carbonate concentration in the melt was relatively high. This trend is consistent with a variation of the carbonate concentration 
230 in the partial melt determined by the weight deficiency of the microprobe analysis

231 (Table 2).

232 4. Discussion

233 4.1. Relationship between conductivity and melt fraction

234

235

236

237

238

239

240

241

242

243

244

245

246

247

248

Carbonate-bearing melts have high wetting properties (e.g., Hunter and

McKenzie, 1989; Minarik and Watson, 1995; Hammouda and Laporte, 2000). The

previous works which determined dihedral angle of olivine-basalt and olivine-

carbonatite systems have shown similar values $\left(20 \sim 30^{\circ}\right)$, which is much less than a critical value $\left(60^{\circ}\right)$ for interconnection (Hunter and McKenzie, 1989; Waff and Bulau, 1979; Yoshino et al., 2009b). Partial melt should form interconnected liquid networks at olivine grain boundaries even at very low-volume fractions and should therefore contribute to the bulk rock conductivity. Thus, a large change of melt connectivity with melt fraction is not expected in the present system. If there was no threshold for the interconnection, a relationship between conductivity $\left(\sigma_{\text {bulk }}\right)$ and melt fraction $(\phi)$ can be expressed by mixing models such as Hashin-Shtrikman upper bound. The previous studies of the partial molten system with the constant melt composition demonstrated a linear relationship in the $\log \sigma-\log \phi$ plot, which is known as the Archie's law (Archie, 1942). Archie's relationship can be expressed as follows:

$$
\sigma_{\text {bulk }}=C \phi^{n} \sigma_{\mathrm{m}}
$$

9 where $C$ and $n$ are constants (e.g., Watanabe and Kurita, 1993). The power exponent in Archie's relation should be close to unity for partial molten rocks with wellinterconnected melt geometry and the constant melt composition (Watanabe and Kurita, 1993; ten Grotenhuis et al., 2005; Yoshino et al., 2010). The exponent close to unity is 
also valid for the other mixing models in the system containing the well-interconnected phase.

In this study, the melt fraction in the sample changes with temperature under the constant bulk $\mathrm{CO}_{2}$ composition (Fig. 6). The conductivity of the bulk rock increases with increasing melt fraction in this study, which is in the same tendency with that in the previous study, where $\mathrm{CO}_{2}$ concentration is constant not in the bulk rock but in the melt (Yoshino et al., 2010). However, an increase of conductivity values with melt fraction in this study is smaller than that in the previous study. The present system yields much smaller exponent for Eq. (2), namely $n=0.58$. In addition, the conductivity values of dolomite melt, which is an end member of this system, does not agree with the extrapolated trend (Fig. 6).

The Archie's law is only applicable to the system with constant melt conductivity. Thus, the "apparent" low power exponent $(n=0.58)$ obtained in this study contains information about variation in melt conductivity with melt fraction. There are two factors to vary the melt conductivity. One is temperature and the other is the $\mathrm{CO}_{2}$ concentration in the partial melt. First we consider thermal effect. The melt conductivity generally increases with increasing temperature followed by Arrhenian relation. If we consider the sample conductivity at $1700 \mathrm{~K}$ in order to directly compare the results of our previous study (Yoshino et al., 2010), the power exponent would be much smaller than 0.58 , because the conductivity measured at lower temperature is relatively higher than that determined at higher temperature. Such a low exponent value $(<0.58)$ further increases the deviation from that $(\sim 1)$ expected from the partial molten rocks with a constant melt composition. Therefore, temperature is not controlling factor.

Next we consider the effect of melt composition on the "apparent" low power exponent. Gaillard et al. (2008) reported that carbonate melt has a distinctly higher electrical conductivity than silicate melt. In the carbonate-bearing peridotite system, the 
conductivity of the partial melt is expected to be controlled by the $\mathrm{CO}_{2}$ content in the partial melt. In general, carbonatitic partial melts containing $\sim 40 \mathrm{wt} . \% \mathrm{CO}_{2}$ are stable only in a limited temperature range above the solidus (Dalton and Presnall, 1998; Gudfinnsson and Presnall, 2005; Dasgupta and Hirschmann, 2006; 2007; Dasgupta et al., 2007). As the temperature approaches to the carbonate-free dry peridotite solidus temperature, the reaction of carbonatite melts with silicate minerals in peridotite produces carbonated silicate melts with a lower $\mathrm{CO}_{2}$ concentration (Moore and Wood, 1998; Dalton and Presnall, 1998; Gudfinnsson and Presnall, 2005; Dasgupta et al., 2007). For example, Dasgupta et al. (2007) showed that the transition from carbonatite (40 wt. \% $\mathrm{CO}_{2}$ ) to carbonated silicate melt $\left(\leq 25 \mathrm{wt} . \% \mathrm{CO}_{2}\right.$ ) in carbonate-bearing peridotiteat $3 \mathrm{GPa}$ occurs abruptly at $1623 \mathrm{~K}$. This study also showed that the $\mathrm{CO}_{2}$ content in the partial melt is even lower at higher temperatures $\left(\sim 13 \mathrm{wt} . \% \mathrm{CO}_{2}\right.$ at 1700 $\mathrm{K})$. Our measurement demonstrated that, at low melt fraction ( $\sim 1 \mathrm{vol} . \%)$, the conductivity values are similar to those of the olivine-carbonatite system (at $1650 \mathrm{~K}$ ), whereas at higher melt fraction $(>10$ vol.\%), the conductivity values are rather closer to those of the olivine-basalt system measured at $1.5 \mathrm{GPa}$ (Yoshino et al., 2010). Thus the expected trend of the conductivity-melt fraction of the present system approaches to that of the olivine-carbonatite $\left(40 \mathrm{wt} . \% \mathrm{CO}_{2}\right)$ and the olivine-basalt trends at lower $(<0.3$ vol.\%) and higher (> 10 vol.\%) melt fractions, respectively. As a result the small $n$ value obtained in the investigated range of melt fraction can be attributed to the decrease of conductivity with carbonate content in the melt by increasing the annealing temperature.

\subsection{Estimation of liquid conductivity as a function of carbonate content}

We next estimate the electrical conductivity of the carbonate-bearing melt itself as a function of the $\mathrm{CO}_{2}$ concentration in the melt to compare it directly with melts with 
various $\mathrm{CO}_{2}$ concentrations at constant temperature $(1700 \mathrm{~K})$. To do this, we made the following two simple assumptions:

1) Electrical conductivity of the partial melt is proportional to the melt fraction. For example, when the bulk conductivity of the sample with 10 vol.\% melt fraction is $10 \mathrm{~S} / \mathrm{m}$, the melt conductivity can be calculated as $100 \mathrm{~S} / \mathrm{m}$. This assumption can be justified since the power exponent $n$ in Eq. (2) for partially molten rocks has a value close to unity (Watanabe and Kurita, 1993; Roberts and Tyburczy, 2000; ten Grotenhuis et al., 2005; Yoshino et al., 2010). In addition, if a difference between solid and melt conductivities exceeds 3 orders of magnitude, the exponent estimated from the HashinShtrikman upper bound, which is frequently used for the melt-bearing system, yields approximately unity for a case that melt fraction is above 0.01 .

2) The effect of temperature on the conductivity of the melt is controlled by the activation enthalpy for electrical conductivity of the melts. The activation enthalpy of dolomite melts was $38 \mathrm{~kJ} / \mathrm{mol}$ at $3 \mathrm{GPa}$. On the other hand, the average activation enthalpies of basaltic melt are more than three times higher (110-150 kJ/mol) (Tyburczy and Waff, 1983; Gaillard and Marziano, 2005). Thus, the temperature dependence of the conductivity of the carbonate melts is much smaller than that of silicate melts. Since silicate melts are likely to polymerize as the $\mathrm{SiO}_{2}$ component in the melt increases, its activation enthalpy would increase with the increasing $\mathrm{SiO}_{2}$ component in the carbonate melt. In the present study, the $\mathrm{CO}_{2}$ concentration in the melt varies considerably.

Therefore, the activation enthalpy is expected to gradually increase with decreasing $\mathrm{CO}_{2}$ concentration in the melt, because there is a negative-correlation between the $\mathrm{SiO}_{2}$ and $\mathrm{CO}_{2}$ concentrations in the carbonate melt (Table 2).

The calculation scheme was as follows. First of all, the absolute conductivity values of melt at temperature we measured were calculated based on the first assumption that conductivity is proportional to melt fraction. To compare the 
conductivity for each carbonate melt at constant temperature, the Arrhenian relation (Eq. 1) was used. The pre-exponential factors $\left(\sigma_{0}\right)$ for each carbonate melt were calculated from the present data for two fixed activation enthalpies (38 and $150 \mathrm{~kJ} / \mathrm{mol}$ ), because once the activation enthalpy is assumed, the unknown parameter in Eq. (1) is only $\sigma_{0}$. The calculated parameters are shown in Table 3 . The $\sigma_{0}$ calculated using high activation energy $(150 \mathrm{~kJ} / \mathrm{mol})$ yields higher values. Indeed, the activation enthalpy should change with the carbonate component in the melt. To estimate more realistic melt conductivity, the activation enthalpy was assumed to be a linear relation between pure carbonate (38 $\mathrm{kJ} / \mathrm{mol})$ and pure silicate melts $(150 \mathrm{~kJ} / \mathrm{mol})$. Further calculation scheme was the same as those presented earlier. The used parameters are also shown in Table 3. The conductivities at $1700 \mathrm{~K}$ were calculated from Eq. (1) using the $\sigma_{0}$ determined by this study.

Fig. 7a shows the logarithmic plot of the electrical conductivity of the partial melt in the KLB1 + dolomite 3 wt. \% system as a function of the $\mathrm{CO}_{2}$ concentration in the melt at $1700 \mathrm{~K}$. Although the log of electrical conductivity was calculated using a possible range of activation enthalpies, the activation enthalpy for the melt conductivity with higher $\mathrm{CO}_{2}$ concentration ( $>40$ wt. \%) should be low and close to that of dolomite melt $(38 \mathrm{~kJ} / \mathrm{mol})$, whereas that with lower $\mathrm{CO}_{2}$ concentration should be higher and approach that of silicate melt $(110-150 \mathrm{~kJ} / \mathrm{mol})$. Considering the effect of the $\mathrm{CO}_{2}$ concentration on activation enthalpy for the melt conductivity, the expected trend of the electrical conductivity of the carbonate-bearing melt, which is in equilibrium with peridotite, shows a large decrease of the electrical conductivity below $40 \mathrm{wt} . \%$ of $\mathrm{CO}_{2}$ (yellow arrows in Fig. 7a). The extrapolation of the melt conductivity to zero $\mathrm{CO}_{2}$ agrees well with the basaltic melt conductivity (TW83: Tyburczy and Waff, 1983; KAB: Pommier et al., 2010). A variation of the estimated melt conductivity as a function of $\mathrm{CO}_{2}$ concentration shows a plateau between 33 and $20 \mathrm{wt} . \% \mathrm{CO}_{2}$. If there exists a threshold for interconnection of chains of silicate tetrahedral in melt, an abrupt 
change of melt conductivity and its activation enthalpy might be present. On the other hand, the conductivity of the melt with higher $\mathrm{CO}_{2}$ concentration is quite consistent with that of dolomite melt measured at $3 \mathrm{GPa}$, which is lower than those of the alkali carbonate melt determined at atmospheric pressure (Gaillard et al., 2008). One explanation for this discrepancy between dolomite and alkali carbonate melt is a negative pressure dependence on the melt conductivity. Although Tyburczy and Waff (1983) reported a negative pressure effect on silicate melts, which are highly polymerized, there has been no relevant conductivity data for carbonate melts as a function of pressure. According to Gaillard et al. (2008), there is a strong correlation between viscosity and conductivity. However, the viscosity of carbonate melts has little pressure effect (Dobson et al., 1996). Another explanation is that the carbonatite melt has a relatively lower conductivity than the carbonate compound composed of alkali elements such as $\mathrm{Na}$ and $\mathrm{K}$ measured by Gaillard et al. (2008).

Fig. $7 \mathrm{~b}$ shows the conductivity enhancement by the carbonate component in the melt as a function of temperature. The conductivity of carbonate-bearing melt increases more than an order of magnitude with increasing $\mathrm{CO}_{2}$ concentration in the melt from 13 to $45 \mathrm{wt} . \%$. The effect of the carbonate component in the partial melt becomes significantly larger with increasing $\mathrm{CO}_{2}$ concentration, especially for higher than 40 wt. $\%$ of $\mathrm{CO}_{2}$. As the temperature increases, the conductivity dependence on $\mathrm{CO}_{2}$ becomes smaller because of the much lower activation enthalpies for melts with higher $\mathrm{CO}_{2}$. It is concluded that the effect of the carbonate melt on the bulk rock conductivity is larger at relatively lower temperatures.

\subsection{Geophysical implications}

The present study showed that electrical conductivity in carbonate-bearing peridotite increases by a limited magnitude with increasing temperature. Only at very low melt fractions and low temperatures just above the carbonate-bearing peridotite 
solidus, the partial melting is very effective in raising the electrical conductivity of the upper mantle. Therefore, in this section, we discuss only geological settings in which the carbonate melt has very high $\mathrm{CO}_{2}$ concentration ( $>40$ vol. \%). Fig. 8 shows the conductivity-depth profile as a function of the melt fraction of carbonatite based on the extrapolation of the trend in Fig. 6. In this figure, the temperature and pressure effects on the conductivity were ignored, because activation enthalpy and volume for electrical conductivity of carbonate melt are very small (Gaillard et al., 2008).

Dasgupta and Hirschmann (2006) experimentally demonstrated that the solidus temperature of carbonate peridotite is lower than the upper mantle adiabatic geotherm below the depth of $330 \mathrm{~km}$. In addition, Hirschmann (2010) predicted that carbonatite melt can exist below $150 \mathrm{~km}$ depth beneath the oceanic lithosphere based on the thermodynamic model assuming the typical volatile contents (100 wt. ppm for $\mathrm{H}_{2} \mathrm{O}$ and 60 wt. ppm for $\mathrm{CO}_{2}$ ). Thus the conductivity anomaly in such a depth region (150 330 $\mathrm{km})$ can be explained by the presence of very small amount of carbonate melt in peridotite. The deep electrical conductivity profile beneath the northwestern Pacific from Hawaii to North America, showed a conductivity anomaly of $10^{-1} \mathrm{~S} / \mathrm{m}$ at a depth of 200-250 km (Lizarralde et al., 1995). The conductivity of the partial molten peridotite with a trace amount of carbonatitic melt should be similar to that of the olivine-carbonatite system, because the carbonate concentration in the partial melt of the carbonate peridotite is significantly high when the degree of melting is very low. If this anomaly originates from the presence of carbonatite melt, the melt fraction can be estimated to be less than 0.5 vol.\% at that depth (Fig. 8). However, only peridotite with at least $3000 \mathrm{ppm}$ of $\mathrm{CO}_{2}$ could achieve this value from a carbonatite melt with high $\mathrm{CO}_{2}$ concentration.

A recent one-dimensional (1-D) electrical conductivity model beneath the Philippine Sea revealed an abrupt increase in the conductivity at around $75 \mathrm{~km}$ of the 
upper mantle depths and a constant conductivity at a depth of $75-300 \mathrm{~km}$ with approximately $0.03 \mathrm{~S} / \mathrm{m}$ (Baba et al., 2010). The seismic tomography indicates cold slabs currently stagnant beneath the region around the Philippine Sea (Fukao et al., 1992). The subducted slab can add carbonate materials through degassing or melting to the above mantle wedge. The added $\mathrm{CO}_{2}$ or carbonate melt can raise the conductivity in this region even if the temperature in this region is significantly lower than that in the surrounding mantle. The conductivity value $0.03 \mathrm{~S} / \mathrm{m}$ can be explained by a presence of 0.1 vol. $\%$ of carbonatitic melt (Fig. 8). Note that the depth of the abrupt increase in the conductivity ( $75 \mathrm{~km}$ depth) is close to the lower bound of the stabilization of the carbonate melt (e.g., Dalton and Presnall, 1998). We suggest that the large decrease in conductivity above this depth should be attributed to the release of $\mathrm{CO}_{2}$ from the carbonate melt because of its strong pressure dependence. Seismic evidence for a sharp lithosphere-asthenosphere boundary beneath the Philippine Sea (Kawakatsu et al., 2009) could also imply the presence of carbonate melt in the upper part of the asthenosphere.

\section{Conclusion}

We performed electrical conductivity measurement at $3 \mathrm{GPa}$ to elucidate the changes in the electrical conductivity of partially molten carbonate-bearing peridotite as functions of the melt fraction and $\mathrm{CO}_{2}$ concentration in the melt. When degree of melting is low ( $<$ a few volume $\%$ ), the conductivity of the carbonatitic melt is distinctly higher than that of carbon-free silicate melt. Although the conductivity of the partial molten peridotite increases with increasing temperature, the degree of the increase in the electrical conductivity is obviously small compared with a case in which the melt composition is constant. We identified that the conductivity changes as a consequence of both an increase in the melt fraction and a decrease in the correlated carbonate concentration in the partial melt with increasing temperature. Carbonate is identified as 
the dominant charge carrier and the conductivity changes of the partial molten rocks are attributed to change in the carbonate mobility controlled by the chemical composition of the melt. When $\mathrm{CO}_{2}$ concentration in the melt decreases to $0 \mathrm{wt} . \%$, the estimated melt conductivity approaches to that of basaltic melt. Although the partial melt with $10 \mathrm{wt} . \%$ $\mathrm{CO}_{2}$ at higher temperatures has slightly higher conductivity than basaltic melt, the enhancement of electrical conductivity by the carbonate melt is the most effective in a temperature range just above the carbonate peridotite solidus temperature. The electrical conductivity of the partially molten region with carbonate in the upper mantle would increase significantly for the case where the degree of melting is very small $(<1$ vol.\%). Petrological knowledge of carbonate concentration in the partial molten rocks is needed to estimate the melt fraction from the geophysical signature of the upper mantle.

\section{Acknowledgements}

The authors are grateful to E. Ito, D. Yamazaki, N. Tomioka, H. Utada, K. Baba, K. Fuji-ta, M. Ichiki, and E. Takahashi for beneficial discussions and to C. Oka for technical assistance. Comments by two anonymous reviewers were useful in improving this paper. This work was supported by a Grant-in-Aids for Scientific Research, No. 20340120 to TY from the Japan Society for Promotion of Science. It was also supported by the internship program (MISIP09) of the Institute for Study of the Earth's Interior, Okayama University.

\section{References}

Archie, G.E., 1942. Electrical resistivity log as an aid determining some reservoir characteristics. Trans. Am. Inst. Min. Metall. Pet. Eng. 146, 54-62.

Baba, K., Chave, A.D., Evans, R.L., Hirth, G., Mackie, R.L., 2006. Mantle dynamics beneath the East Pacific Rise at 17 S: Insights from the Mantle Electromagnetic and 
459

460

461

462

463

464 465

466

467

468

469

470

471

472

473

474

475

476

477

Tomography (MELT) experiment. J. Geophys. Res. 111, B02101, doi:10.1029/2004JB003598.

Baba, K., Utada, H., Goto, T., Kasaya, T., Shimizu, H., Tada, N., 2010. Electrical conductivity imaging of the Philippine Sea upper mantle using seafloor magnetotelluric data. Phys. Earth Planet. Int. 183, 44-62.

Constable, S., 2006. SEO3: A new model of electrical conductivity. Geophys. J. Int. 166, 435-437.

Dalton, J.A., Presnall, D.C., 1998. Carbonatitic melts along the solidus of model lhelzolite in the system $\mathrm{CaO}-\mathrm{MgO}-\mathrm{Al}_{2} \mathrm{O}_{3}-\mathrm{SiO}_{2}-\mathrm{CO}_{2}$ from 3 to $7 \mathrm{GPa}$. Contrib. Mineral. Petrol. 131, 123-135.

Dasgupta, R., Hirschmann, M.M., 2006. Melting in the Earth's deep upper mantle caused by carbon dioxide. Nature 440, 659-662.

Dasgupta, R., Hirschmann, M.M., 2007. A modified iterative sandwich method for determination of near-solidus partial melt compositions. II. Application to determination of near-solidus melt compositions of carbonated peridotite. Contrib. Mineral. Petrol. 154, 647-661.

Dasgupta, R., Hirschmann, M.M., Smith, N.D., 2007. High pressure partial melting experiments of peridotite $+\mathrm{CO}_{2}$ and genesis of alkalic ocean island basalts. J. Petrol. 48, $2093-2124$.

Dobson, D.P., Jones, A.P., Rabe, R., Sekine, T., Kurita, K., Taniguchi, T., Kondo, T., Kato, T., Shimomura, O., Urakawa, S., 1996. In situ measurement of viscosity and density of carbonate melts at high pressure. Earth Planet. Sci. Lett. 143, 207-215. 
481 482 483

Evans, R.L., Hirth, G., Baba, K., Forsyth, D., Chave, A., Mackie, R., 2005. Geophysical evidence from the MELT area for compositional controls on oceanic plates. Nature 437, $249-252$.

Falloon, T.J., Green, D.H., 1989. The solidus of carbonated, fertile peridotite. Earth Planet. Sci. Lett. 94, 364-370.

Fukao, Y., Obayashi, M., Inoue, H., Nenbai, M., 1992. Subducting slabs stagnant in the mantle transition zone. J. Geophys. Res. 97, 4809-4822.

Gaillard, F., Iacono-Marziano, G., 2005. Electrical conductivity of magma in the course of crystallization controlled by their residual liquid composition. J. Geophys. Res. 110, B06204, doi:10.1029/2004JB003282.

Gaillard, F., Marki, M., Iacono-Marziano, G., Pichavant, M., Scaillet, B., 2008.

Carbonatite melts and electrical conductivity in the asthenosphere. Science 322, 13631365.

Gudfinnsson, G.H., Presnall, D.C., 2005. Continuous gradations among primary carbonatitic, kimberlitic, melilititic, basaltic, picritic, and komatiitic melts in equilibrium with garnet lherzolite at 3-8 GPa. J. Petrol. 46, 1645-1659.s

Hammouda, T., Laporte, D., 2000. Ultrafast mantle impregnation by carbonatite melt. Geology 28, 283-285.

9 Hampton, N.A., Karunathilaka, S.A.G.R., Leek, R., 1980. Impedance of electrical storage-cells. J. Appl. Electrochem. 10, 3-11.

Hirschmann, M.M., 2010. Partial melt in the oceanic low velocity zone. Phys. Earth Planet. Int. 179, 60-71. 
Hunter, R.H., McKenzie, D., 1989. The equilibrium geometry of carbonate melts in rocks of mantle composition. Earth Planet. Sci. Lett., 92, 347-356.

Jegen, M., Edwards, R.N., 1998. Electrical properties of a 2D conductive zone under the Juan de Fuca ridge. Geophys. Res. Lett. 25, 3647-3650.

Kawakatsu, H., Kumar, P., Takei, Y., Shinohara, M., Kanazawa, T., Araki, E., Suyehiro, K., 2009. Seismic evidence for sharp lithosphere-asthenosphere boundaries of oceanic plates. Science 324, 499-502

Lizarralde, D., Chave, A.D., Hirth, G., Schultz, A., 1995. A Northern Pacific mantle conductivity profile from long-period magnetotelluric sounding using Hawaii to California submarine cable data. J. Geophys. Res. 100, 17837-17854.

Minarik, W.G., Watson, E.B., 1995. Interconnectivity of carbonate melt at low melt fraction. Earth Planet. Sci. Lett. 133, 423-437.

Moore, K.R., Wood, B.J., 1998. The transition from carbonate to silicate melts in the $\mathrm{CaO}-\mathrm{MgO}-\mathrm{SiO}_{2}-\mathrm{CO}_{2}$ system. J. Petrol. 39, 1943-1951.

Pommier, A., Gaillard, F., Malki, M., Pichavant, M, 2010. Methodological reevaluation of the electrical conductivity of silicate melts. Am. Mineral. 95, 284-291.

Presnall, D.C., Simmons, C.L., Porath, H., 1972. Change of electrical conductivity of a synthetic basalt during melting. J. Geophys. Res. 77, 5665-5672.

Rigden, S.M., Ahrens, T.J., Stolper, E.M., 1984. Densities of liquid silicates at high pressures. Science 226, 1071-1074.

Roberts, J.J., Tyburczy, J.A., 2000. Partial-melt conductivity: Influence of melt composition. J. Geophys. Res. 104, 7055-7065. 
Shankland, T.J., Waff, H.S., 1977. Partial melting and electrical conductivity anomalies in the upper mantle. J. Geophys. Res. 82, 5409-5417.

ten Grotenhuis, S.M., Drury, M.R., Spiers, C.J., Peach, C.J., 2005. Melt distribution in olivine rocks based on electrical conductivity measurement. J. Geophys. Res. 110, B12201, doi:10.1029/2004JB003462.

Tyburczy, J.A., Waff, H.S., 1983. Electrical conductivity of molten basalt and andesite to 25 kilobars pressure: geophysical significance and implications for charge transport and melt structure. J. Geophys. Res. 88, 2413-2430.

van Hassel, B.A., Boukamp, B.A., Burggraaf, A.J., 1991. Electrode polarization at the $\mathrm{Au}, \mathrm{O} 2$ (g)/yttria stabilized zirconia interface. Part I: Theoretical considerations of reaction model. Solid State Ionics, 48, 139-154.

Waff, H.S., Bulau, J.R., 1979. Equilibrium fluid distribution in an ultramafic partial melt under hydrostatic stress conditions. J. Geophys. Res. 84, 6109-6114.

Watanabe, T., Kurita, K., 1993. The relationship between electrical conductivity and melt fraction in a partially molten simple system. Phys. Earth Planet. Int. 78, 9-17.

Yoshino, T., Takei, Y., Wark, D.A., Watson, E.B., 2005. Grain boundary wetness of texturally equilibrated rocks, with implications for seismic properties of the upper mantle. J. Geophys. Res., 110, B08205, doi:10.1029/2004JB003544.

Yoshino, T., Matsuzaki, T., Yamashita, S., Katsura, T., 2006. Hydrous olivine unable to account for conductivity anomaly at the top of the asthenosphere. Nature, 443, 973-976. 
545 Yoshino, T., Matsuzaki, T., Shatzkiy, A., Katsura, T., 2009a. The effect of water on the

546 electrical conductivity of olivine aggregates and its implications for the electrical

547 structure in the upper mantle. Earth Planet. Sci. Lett. 288, 291-300.

548 Yoshino, T., Yamazaki, D., Mibe, K., 2009b. Well-wetted olivine grain boundaries in

549 partial molten peridotites in the asthenosphere. Earth Planet. Sci. Lett. 283, 167-173.

550 Yoshino, T., Laumonier, M., McIsaac, E., Katsura, T., 2010. Electrical conductivity of

551 basaltic and carbonatite melt-bearing peridotites at high pressures: implications for melt

552 distribution and melt fraction in the upper mantle. Earth Planet. Sci. Lett. 295, 593-602. 
553

554

555

Figure captions

Fig. 1. Back-scattered electron images (BEI) of polished samples with a chemical composition of KLB1 + dolomite 3 wt.\% and with various proportions of carbonatebearing melt. (a) Run\# 1K1364, annealed at 1400 K. (b) Run\# 1K1173, annealed at 1500 K. (c) Run\# 1K1174, annealed at 1600 K. (d) Run\# 1K1361, annealed at 1700 K. White bars correspond to $10 \mu \mathrm{m}$.

Fig. 2. Impedance spectra of carbonate-bearing peridotite samples obtained during cooling as a function of temperature. All samples have a bulk composition of the KLB1 + dolomite 3 wt.\%. Samples were annealed at 1500 K (a), 1600 K (b), and 1700 K (c). Note the first semicircular arc at high frequencies followed by a pseudo-inductive part and an additional tail derived from electrode reaction at low frequencies.

Fig. 3. Electrical conductivity of $(\mathrm{Ca}, \mathrm{Mg}) \mathrm{CO}_{3}$ as a function of reciprocal temperature. Note that the conductivity after melting is much higher than that before melting.

Fig. 4. Electrical conductivity of the peridotite-dolomite system as a function of reciprocal temperature. (a) Run\# 1K1173, peridotite with 3 wt.\% carbonatite during the heating (open symbols)-cooling (closed symbols) cycles. (b) All samples for peridotite with and without 3 wt.\% dolomite. The symbols indicate raw data of the cooling path after annealing at the maximum temperature for each sample with different melt fractions. Abbreviations; C06: the latest model of olivine electrical conductivity at 0.1 MPa under IW (iron-wüstite) buffers from Constable (2006). YMYK06: a conductivity range of electrical conductivity of olivine single crystal at $3 \mathrm{GPa}$ under $\mathrm{Ni}-\mathrm{NiO}$ buffer from Yoshino et al. (2006).

Fig. 5. Electrical conductivity and melt fraction versus temperature for the system with KLB1 + 3 wt.\% dolomite. 
Fig. 6. Relationship between the melt fractions and electrical conductivities for the carbonate-bearing partial molten peridotite. Data of the olivine + carbonatitic melts $(1650 \mathrm{~K}$ and $3 \mathrm{GPa})$ with constant $\mathrm{CO}_{2}$ concentration in the melt, and the olivine + basalt melts (1.5 GPa and $1600 \mathrm{~K}$; i.e. no $\mathrm{CO}_{2}$ ) are also plotted (Yoshino et al., 2010). The shaded region indicates a typical range of conductivity values of basaltic melt (e.g. Presnell et al., 1972). The thick dashed line indicates an expected conductivity-melt fraction relation for the carbonate-bearing peridotite system. Star symbol denotes conductivity of dolomite melt, which is an end member of the system used for the present study at $1700 \mathrm{~K}$. Note that the trend of the carbonate-bearing partial molten peridotite (KLB1 + dolomite $3 \mathrm{wt} . \%$ ) is inconsistent with the conductivity value of dolomite melt.

Fig. 7. Log electrical conductivity $\sigma$ of melt in the KLB1 + dolomite $3 \mathrm{wt} . \%$ system as a function of $\mathrm{CO}_{2}$ concentration in the melt. (a) Symbols represent the $\log \sigma$ of the carbonate-bearing melt calculated at $1700 \mathrm{~K}$ assuming various activation enthalpies for the electrical conductivity of the melt. Orange circle represents the conductivity value of dolomite melt at $1700 \mathrm{~K}$. The dashed line denotes the $\mathrm{CO}_{2}$ concentration in dolomite $(\mathrm{Ca}, \mathrm{Mg}) \mathrm{CO}_{3}$. The red square symbols indicate the conductivity values of silicate melt (TW83: Tyburczy and Waff, 1983; KAB, Kilauea alkali basalt: Pommier et al., 2010). The green area indicates the conductivity range of the carbonate melt determined at atmospheric pressure (Gaillard et al., 2008). Note that as $\mathrm{CO}_{2}$ concentration in the melt increases, the conductivity of the partial melt in carbonate-bearing peridotite increases by nearly an order of magnitude. The yellow dashed arrows denote a predicted trend of the melt conductivity. (b) The $\log \sigma$ of the carbonate-bearing melt as a function of $\mathrm{CO}_{2}$ concentration in the melt for different temperatures based on a case for variable activation enthalpy (Table 3 ). Note that as temperature decreases, the conductivity depends more strongly on the $\mathrm{CO}_{2}$ concentration in the melt. 
603 Fig. 8. Melt fraction of carbonatite melt with a high $\mathrm{CO}_{2}$ concentration (> 40 wt. \%)

604 estimated from the reference one-dimensional (1-D) conductivity models obtained by 605 geophysical observations. The yellow colored area denotes the reference 1-D models for 606 the north Pacific obtained by Lizarralde et al. (1995). The red line indicates the 1-D 607 model for the Philippine Sea mantle (Baba et al., 2010). 


\begin{tabular}{|c|c|c|c|c|c|c|}
\hline Run No. & vol. $\%{ }^{\mathrm{a}}$ & $\mathrm{T}_{\max }(\mathrm{K})$ & $\log \sigma_{\max }(\mathrm{S} / \mathrm{m})^{\mathrm{b}}$ & $\mathrm{CO}_{2}(\text { wt. } \%)^{\mathrm{c}}$ & Phase assemblage $^{\mathrm{d}}$ & Remarks \\
\hline \multicolumn{7}{|l|}{ KLB1 } \\
\hline $1 \mathrm{~K} 1178$ & 0 & 1700 & -1.87 & 0 & ol(Fo $\left.{ }_{90}\right)$-opx-cpx-grt & \\
\hline \multicolumn{7}{|c|}{ KLB1 + Dolomite 1 wt.\% } \\
\hline $1 \mathrm{~K} 1161$ & 1.0 & 1400 & -0.25 & n.d. & ol( $\left.\mathrm{Fo}_{90}\right)$-opx-cpx-grt-melt & \\
\hline $1 \mathrm{~K} 1158$ & 20 & - & 0.50 & $5(1)$ & $\mathrm{ol}\left(\mathrm{Fo}_{93}\right)$-melt & Incorrect $\mathrm{T}$ reading \\
\hline \multicolumn{7}{|c|}{ KLB1 + Dolomite 3 wt.\% } \\
\hline $1 \mathrm{~K} 1364$ & 0.5 & 1400 & -0.48 & $\sim 50$ & ol(Fog0)-opx-cpx-grt-dol-melt & \\
\hline $1 \mathrm{~K} 1173$ & 1.8 & 1500 & -0.21 & $45(3)$ & ol( $\left.\mathrm{Fo}_{91}\right)$-opx-cpx-grt-dol-melt & \\
\hline $1 \mathrm{~K} 1174$ & 11 & 1600 & 0.18 & $33(2)$ & ol(Fo93)-cpx-melt & \\
\hline $1 \mathrm{~K} 1363$ & 14.7 & 1650 & 0.49 & $20(1)$ & $\mathrm{ol}\left(\mathrm{Fo}_{93}\right)$-cpx-melt & \\
\hline $1 \mathrm{~K} 1361$ & 20.3 & 1700 & 0.29 & $13(3)$ & ol(Fog2)-cpx-melt & \\
\hline \multicolumn{7}{|l|}{ Dolomite } \\
\hline \multirow[t]{2}{*}{ S2367 } & 100 & 1800 & 2.02 & 47.7 & melt & $\Delta H=38 \mathrm{~kJ} / \mathrm{mol}$ \\
\hline & & & & & & $\sigma_{0}=1343 \mathrm{~S} / \mathrm{m}$ \\
\hline
\end{tabular}

All experiments were conducted at $3 \mathrm{GPa}$.

a: Volume percent of melt phase in run products determined by image analysis.

b: Log conductivity measured at maximum temperature just before quenching.

c: $\mathrm{CO}_{2}$ concentration in melt estimated from the total weight deficit of the EPMA analysis.

d: Abbreviations: ol; olivine, opx; orthopyroxene, cpx; clinopyroxene, grt; garnet, dol; dolomite 
Table 2. Melt composition of run products

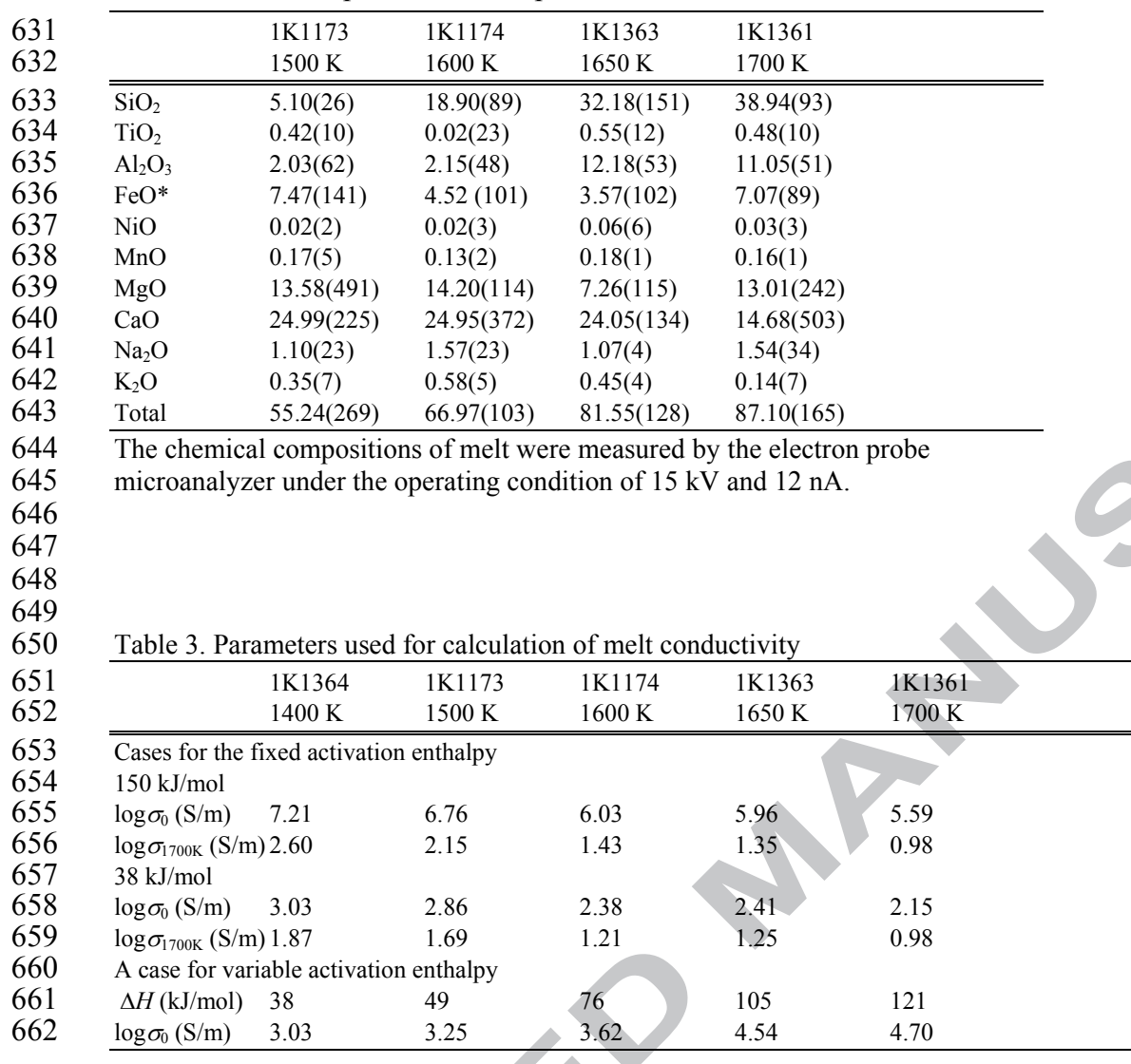



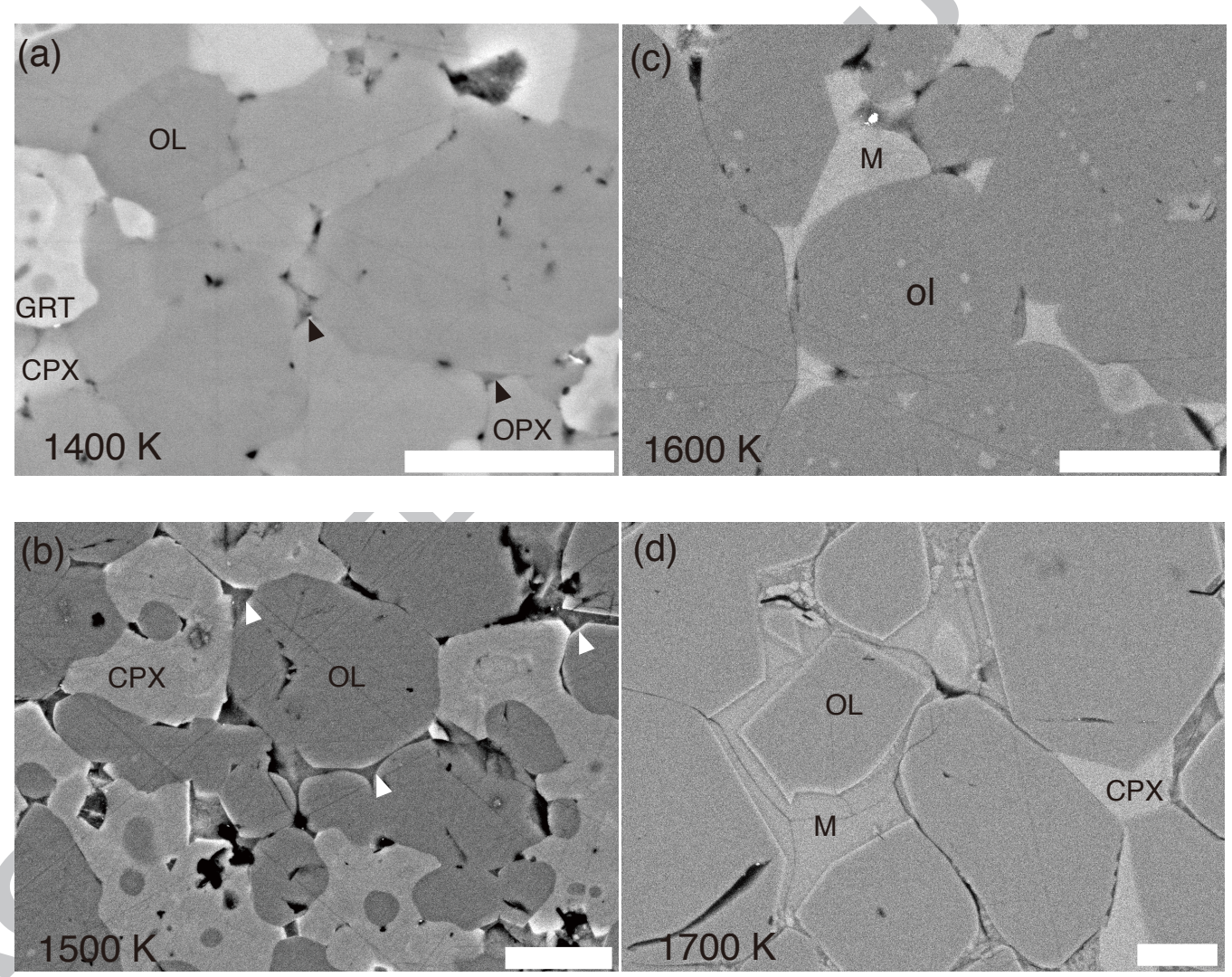

Fig. 1. Yoshino et al. 


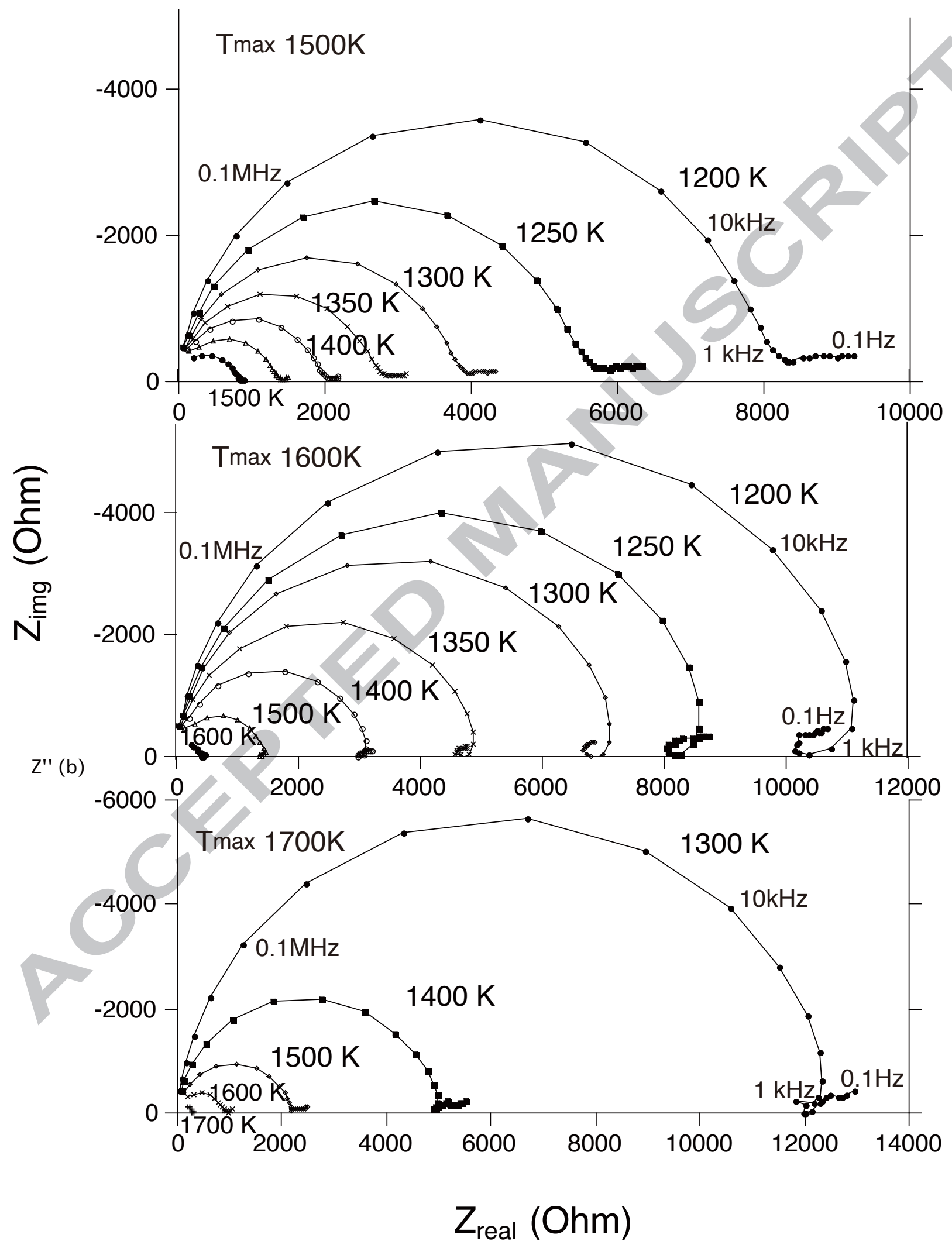

Fig. 2. Yoshino et al. 


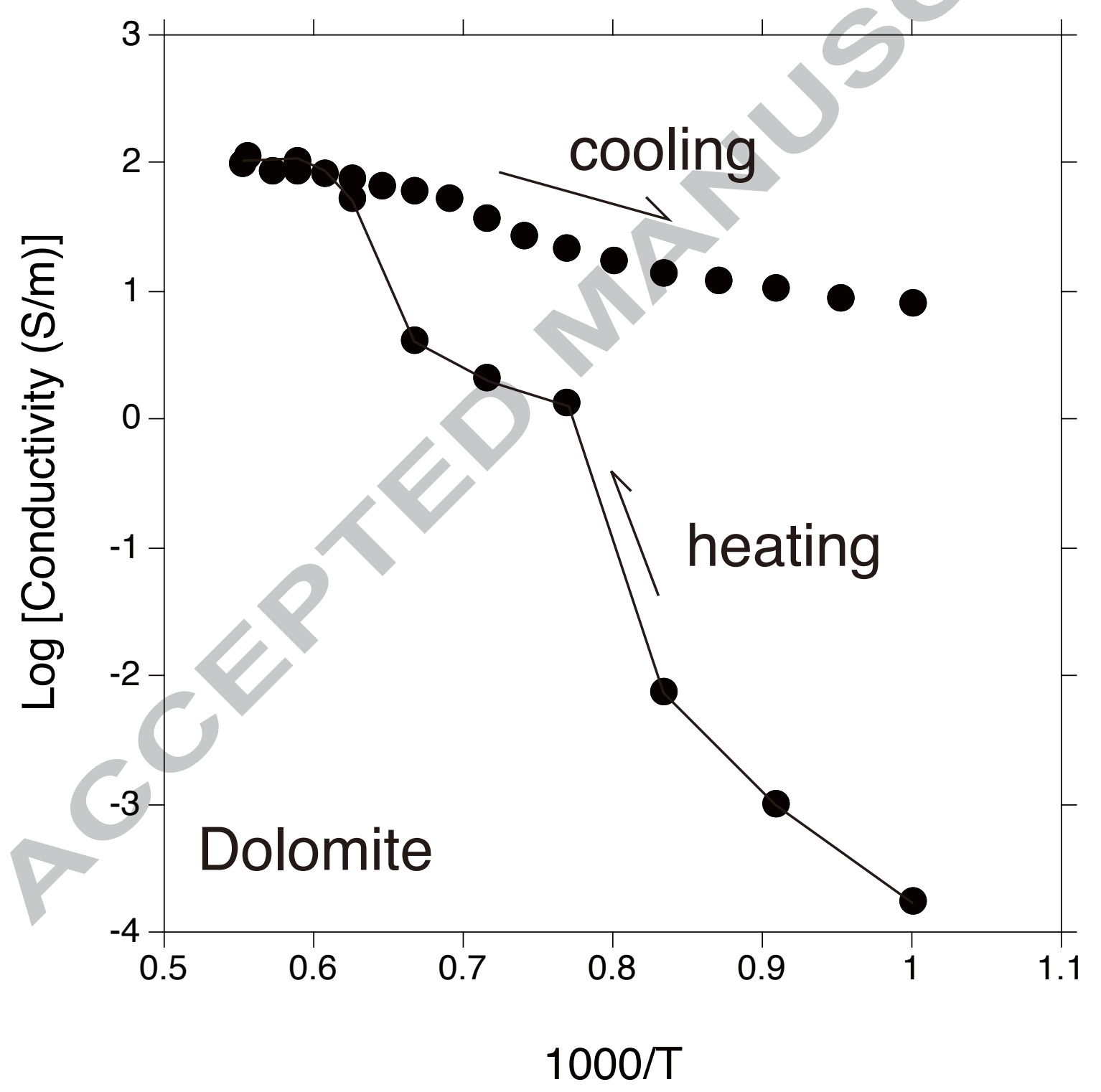

Fig. 3. Yoshino et al. 
(a)

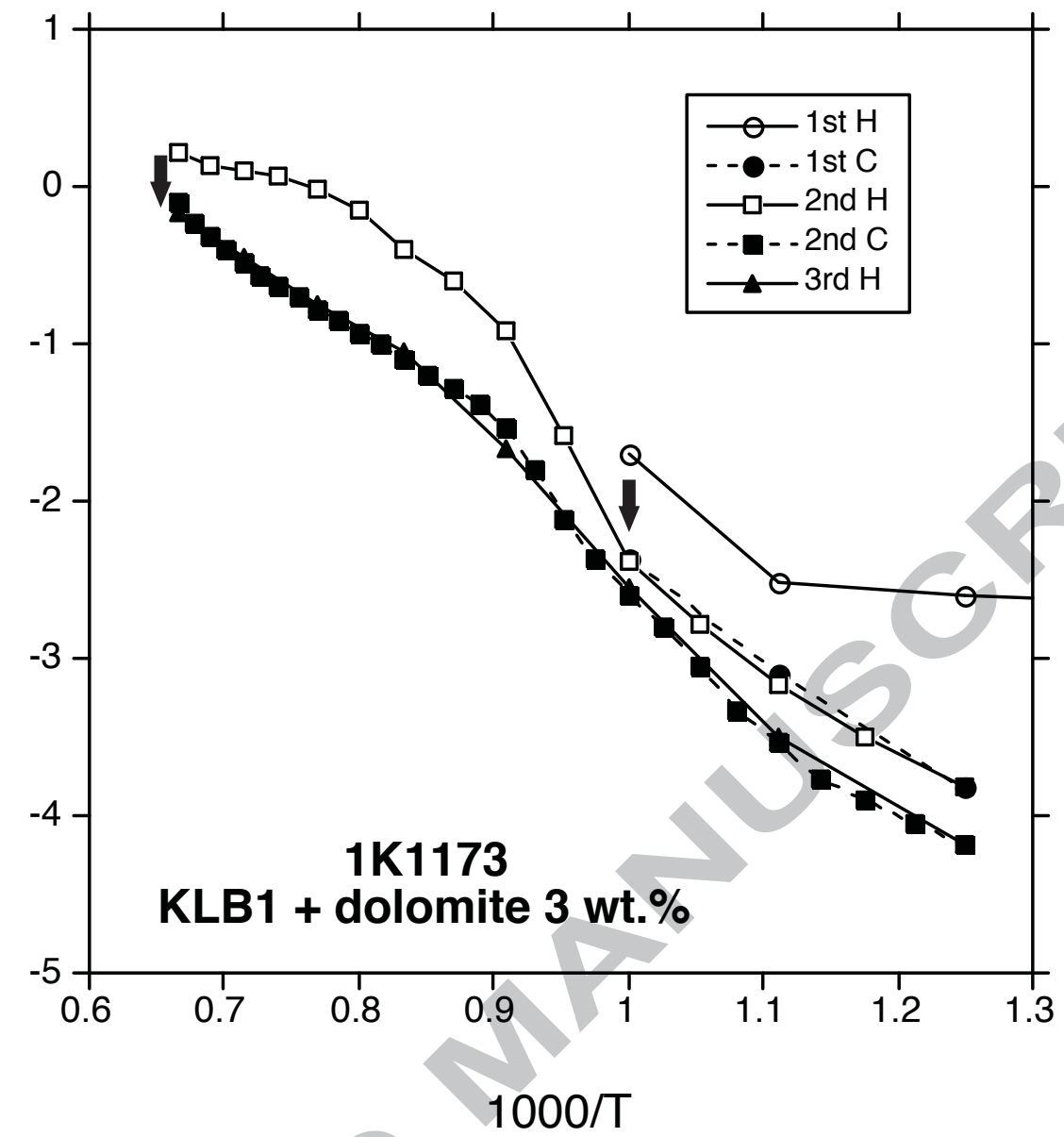

(b)

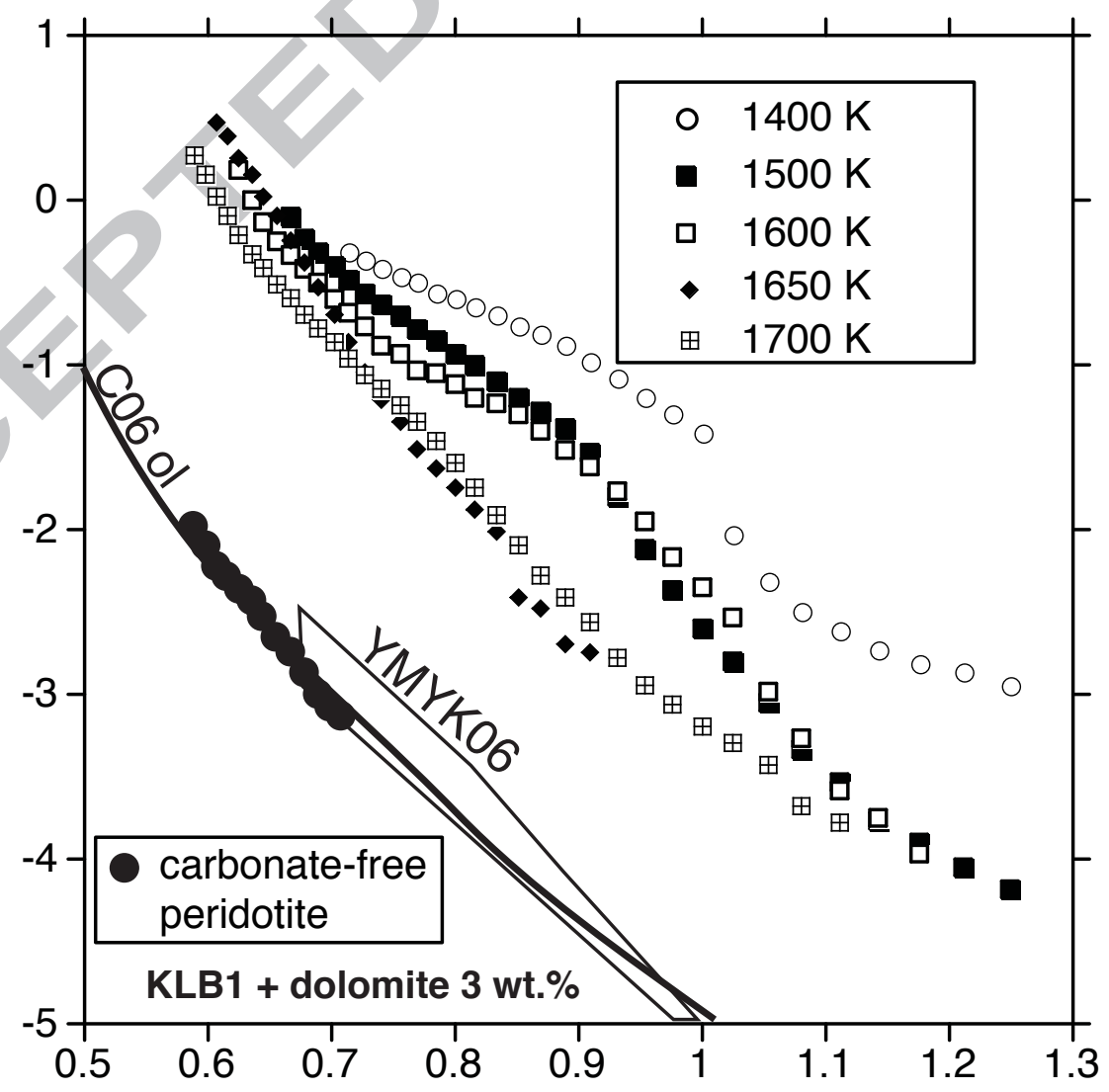

$1000 / T$

Fig. 4. Yoshino et al. 


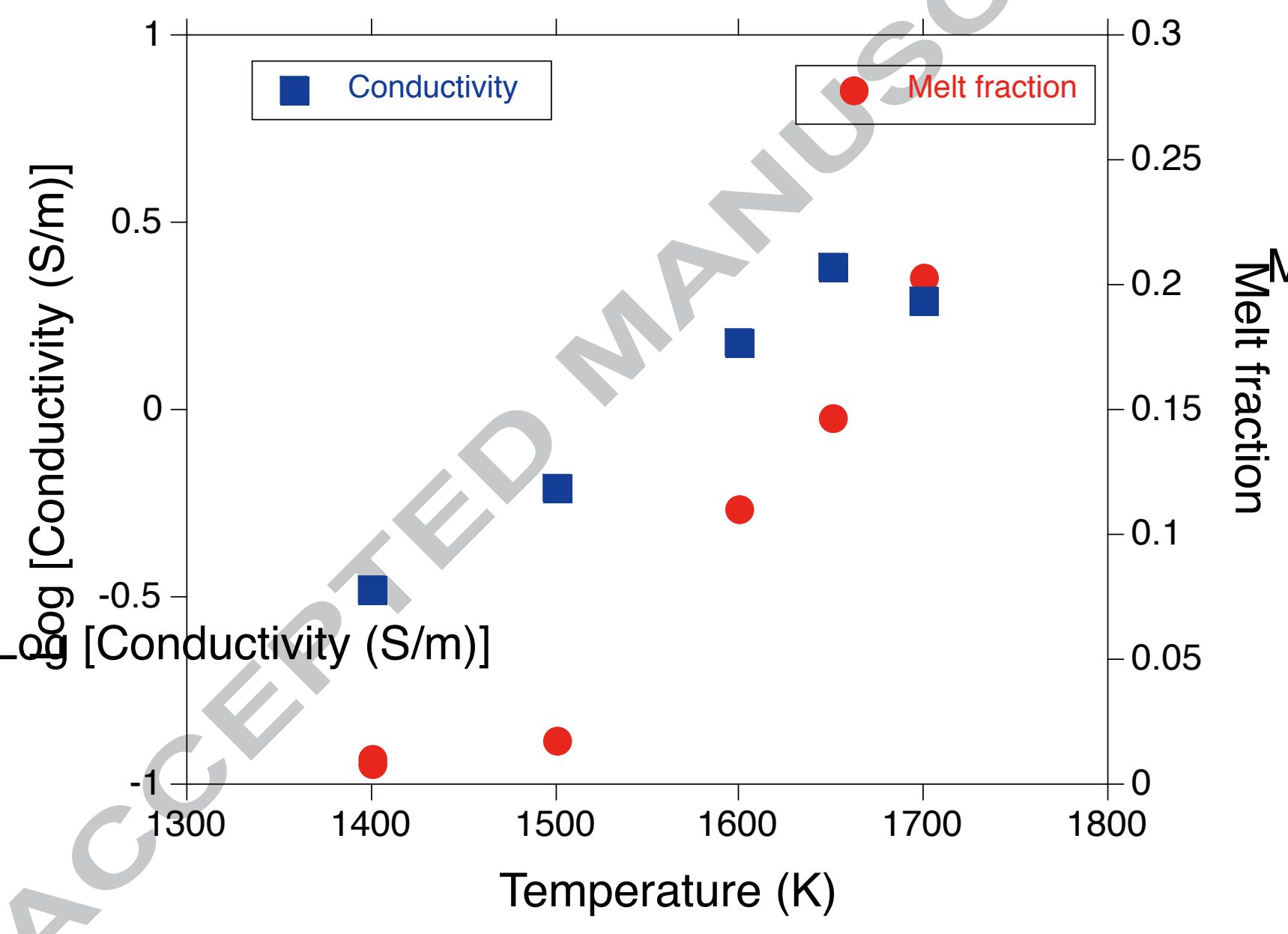

Fig. 5. Yoshino et al. 


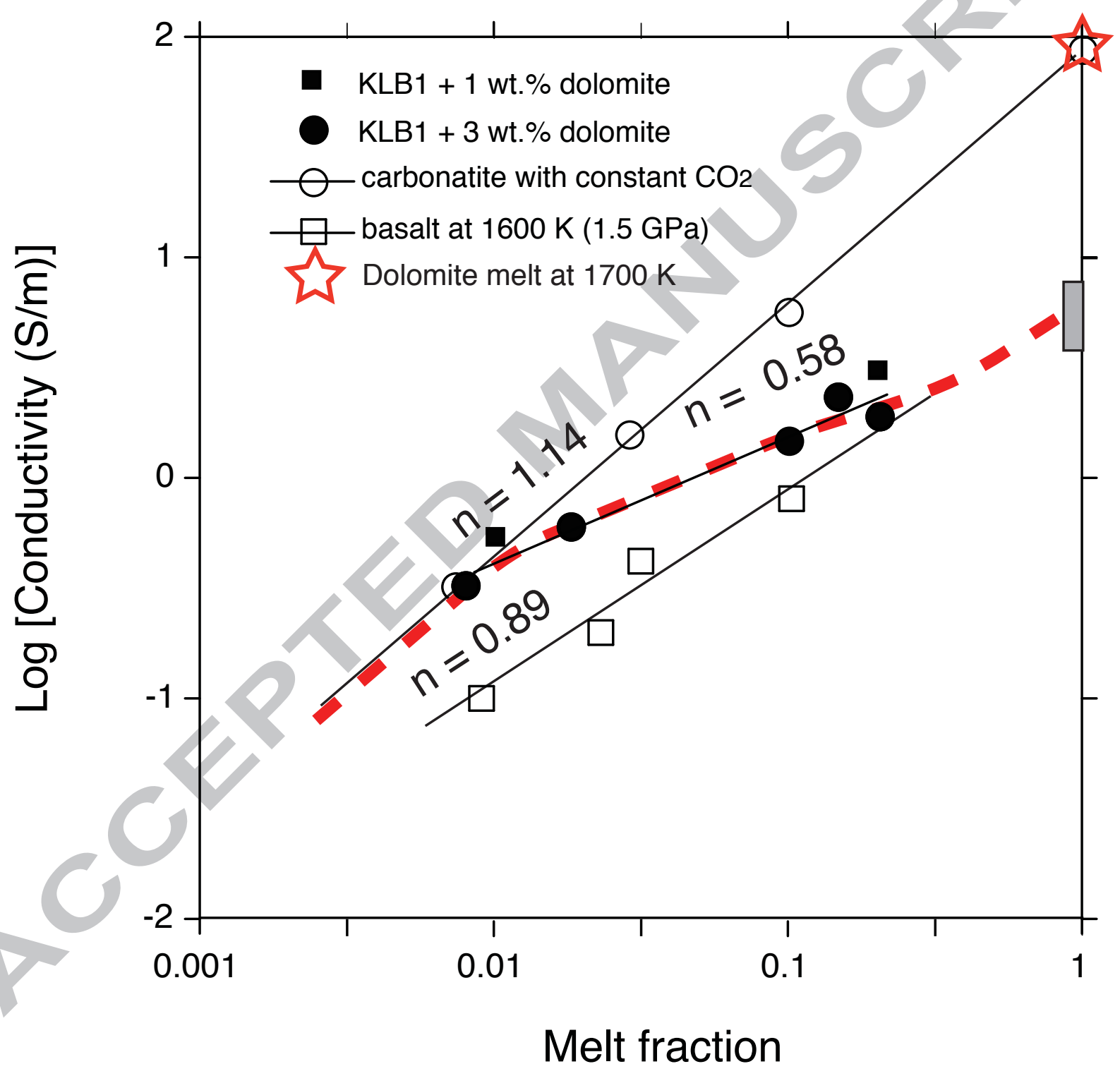

Fig. 6. Yoshino et al. 

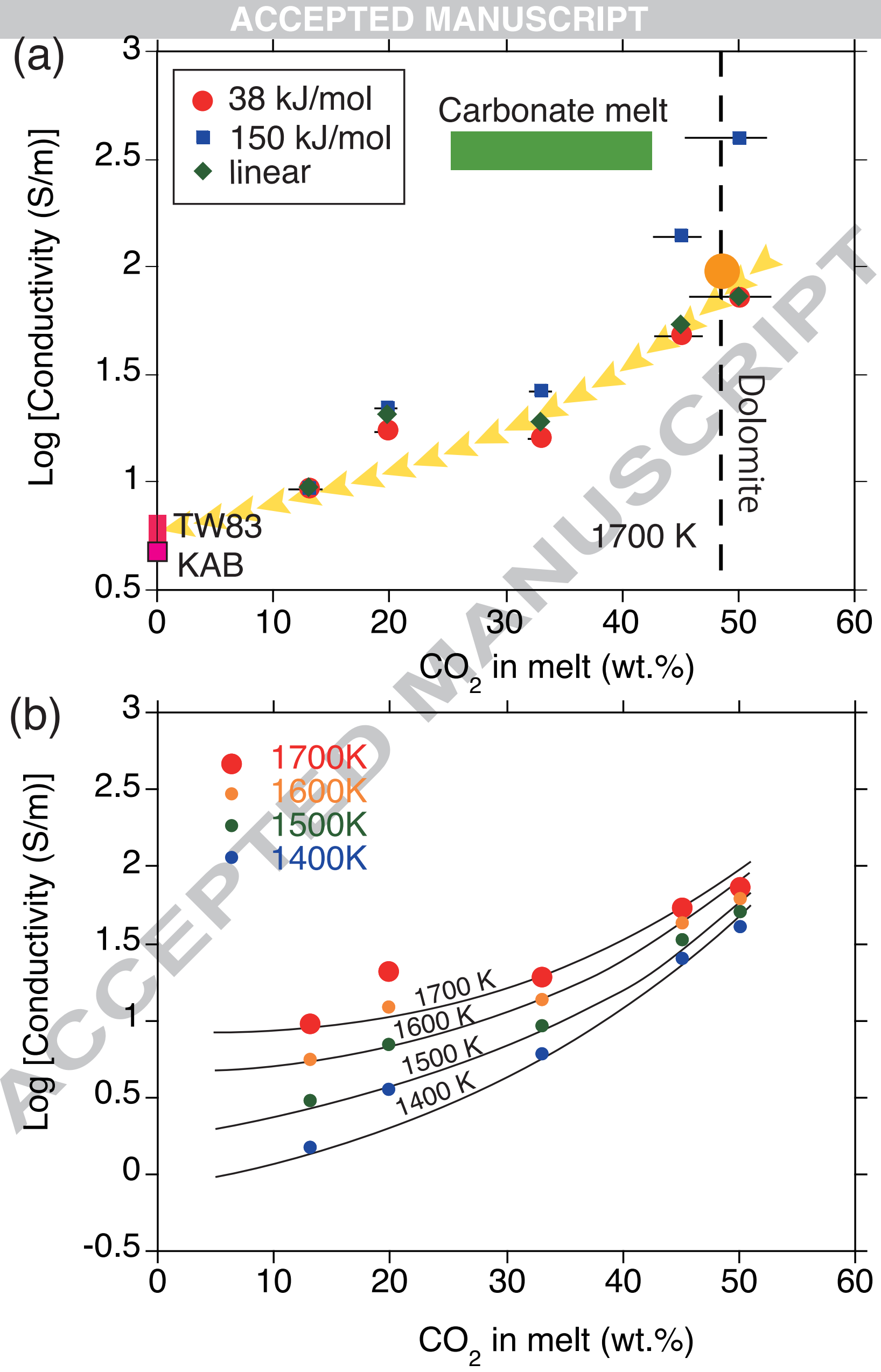

Fig. 7. Yoshino et al. 




Fig. 8. Yoshino et al. 
663

664

665

666

667

668

669

670
Highlights

1. We investigated electrical conductivity of partially molten carbonate peridotite.

2. On the solidus, the conductivity was markedly higher than that of carbonate-free peridotite.

3. Electrical conductivity is not markedly increased by higher melting degree.

4. The moderate increase is attributed to a decrease in carbonate content in the partial melt.

5. The conductivity in the upper mantle is enhanced by very small degree of melting. 